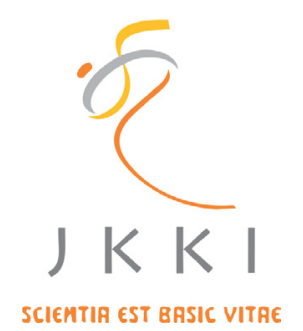

Jurnal Kedokteran dan Kesehatan Indonesia

Indonesian Journal of Medicine and Health

Journal homepage : www.journal.uii.ac.id/index.php/JKKI

\title{
Correlation between the effect of increasing body weight with plantar pressure and ankle-knee radiographic angle parameters changes
}

\author{
Dimas Triaryo $^{* 1}$, Luthfi Hidayat ${ }^{1}$, Rahadyan Magetsari ${ }^{1}$ \\ ${ }^{1}$ Department of Orthopaedics and Traumatology, Faculty of medicine, Universitas Gadjah Mada, Indonesia
}

Original Article

\begin{tabular}{l} 
ART ICLE I N F O \\
\hline Keywords: \\
Body weight increase, \\
BMI, \\
plantar pressure, \\
ankle-knee parameters, \\
Spearman correlation \\
*Corresponding author: \\
dr.dimastriaryo@gmail.com \\
\hline DOI: 10.20885/JKKI.Vol10.Iss1.art5 \\
History: \\
Received: March 2, 2018 \\
Accepted: March 3, 2019 \\
Online: April 30, 2019 \\
\hline
\end{tabular}

Copyright@2019 Authors. This is an open access article distributed under the terms of the Creative Commons Attribution-NonCommercial $\quad 4.0$ International Licence (http:// creativecommons.org/licences/ by-nc/4.0/).

\section{ABSTRACT}

Background: Understanding the biomechanical structure of the body is important to preventingand treating the musculoskeletal system problems. The increase in body mass index contributes to the elevated peak plantar pressure and decreased longitudinal arch of the foot. This condition, consequently, may cause mal-alignment of the lower extremity, leading to promote cartilage breakdown, osteophyte formation, subchondral bone hypertrophy, lead to progression of knee joint destruction and functional deficits.

Objective: The aim of the study was to examine the correlation between body weight, plantar pressures, ankle and knee angle measurement parameters.

Methods: The research study sample included 30 female who met inclusion and exclusion criteria. In order to evaluate the structural characteristic of plantar foot, we used the blueprint method on bare-foot and also when carrying 15 and 25 kilogram of load. Furthermore, to measure knee-angle parameters, we also performed a bilateral standing radiograph approach of lower extremity.

Results: This study showed a significant correlation between BMI/Body mass index and HW/heel width $(\mathrm{p}=0,00)$ with low positive correlation for both sides. Furthermore, BMI and PAW/plantar arch width $(p=0,00)$ showed a moderate positive correlation for both sides. In contrast to that, BMI and MFA/mid-foot area $(p=0,00)$ showed a moderate positive correlation for the right side but low positive correlation for the left side. Another measurement such as BMI and AI/arch index $(\mathrm{p}=0,00)$ had a strong positive correlation on the right side and moderate positive correlation on the left side. Moreover, BMI and AAL/Ankle angle alignment $(p=0,00)$ revealed a strong positive correlation for both sides, BMI and XCTP/trans-condylar tibial plateau angle $(\mathrm{p}<0,05)$ had a low positive correlation for both sides, meanwhile BMI and AA/ankle angle $(p=0,00)$ showed a low positive correlation for both sides.

Conclusion: Increasing axial load was statistically significant correlated with increasing plantar pressure and ankle-knee radiographic angle parameter. The results also revealed that increasing axial load was found to have strong correlation to the arch index (AI) and ankle angle alignment (AAL). It was a compensatory phenomenon, which can cause structural disturbances and function of the lower limb. 
sistem muskuloskeletal. Peningkatan massa tubuh diketahui berkontribusi pada peningkatan tekanan plantar dan penurunan lengkungan lengkung kaki. Kondisi tersebut dapat menyebabkan malalignment pada ekstremitas bawah, yang dapat menyebabkan kerusakan kartilago, pembentukan osteofit, hipertrofi subchondral, kerusakan sendi dan gangguan fungsi.

Tujuan: Tujuan dari penelitian ini adalah untuk menemukan hubungan antara berat badan, tekanan plantar, parameter sudut pergelangan kaki dan sudut pada sendi lutut.

Metode: Sampel penelitian meliputi 30 wanita yang memenuhi kriteria inklusi dan eksklusi. Metode cetak biru digunakan untuk mengevaluasi karakteristik struktur plantar kaki, dan juga saat membawa beban 15 kilogram dan 25 kilogram. Para peserta berdiri di atas kertas kosong dan juga didokumentasikan pergelangan kaki dari belakang dengan foto kamera. Parameter pengukuran sudut pergelangan kaki dan lutut menggunakan pendekatan radiografi.

Hasil: Dalam penelitian ini menunjukkan hubungan yang signifikan antara variabel IMT (Index massa tubuh) dengan HW (Heel width), PAW (Plantar arch width), MFA (Midfoot area), AI (Arch index), AAL (Ankle angle alignment), XCTP (Condylar plateau angle) dan $A A$ (Arch angle) ( $p<0,05)$, dengan kekuatan hubungan sebagai berikut, IMT dan HW $(p=0,00)$ menunjukkan korelasi positif rendah untuk kedua sisi, IMT dan PAW $(p=0,00)$ menunjukkan korelasi positif sedang untuk kedua sisi, IMT dan MFA ( $p=0,00)$ menunjukkan korelasi positif sedang untuk sisi kanan dan korelasi positif rendah untuk sisi kiri,BMI dan AI $(p=0,00)$ menunjukkan korelasi kuat positif untuk sisi kanan dan korelasi positif sedang untuk sisi kiri, IMT dan $A A L(p=0,00)$ menunjukkan korelasi positif yang kuat untuk kedua sisi, IMT dan XCTP $(p<0,05)$ menunjukkan korelasi positif rendah untuk kedua sisi, IMT dan AA ( $p=0,00)$ menunjukkan korelasi positif rendah untuk kedua sisi.

Kesimpulan: Peningkatan berat badan memiliki korelasi yang signifikan secara statistic dengan peningkatan tekanan plantar dan ankle-knee radiologi parameter. Hasil penelitian menunjukkan hubungan yang kuat antara peningkatan berat badan dengan AI (arch index) dan AAL (ankle angle alignment). Hasil ini mencerminkan adanya hubungan kompensasi yang dapat menyebabkan gangguan struktur dan fungsi pada ektremitas bawah.

\section{INTRODUCTION}

Understanding the biomechanical structure of each part of the body is essential to prevent and treat musculoskeletal system disorders. ${ }^{1}$ Increasing body weight affects the ability to undertake daily activities and increases the intensity of pain. ${ }^{2}$ Body weight is transmitted from the vertebral column through the pelvis and lower extremities, especially the feet. ${ }^{3}$ The feet, consequently, become the contact point with the ground to absorb forces while walking or standing. Furthermore, these structures are evolving and adaptive to changes in both weights and the ground surface. ${ }^{3}$

The width of the pelvis in women is prolonged than men, which results in changes in the distance between the anatomical axis and the vertical axis. This causes the $\mathrm{Q}$-angle value in women to be greater than men. Theoretically, higher Q-angle can initiate patellofemoral disorders. Also, weight gain is associated with increased plantar midfoot pressure and functional limitations related with the foot. ${ }^{2,4}$ The significant results of a study performed by Tomankova (2015), showed that excess body weight is a potential predictor of greater plantar pressure peak under the midfoot. ${ }^{5}$ Increasing midfoot plantar pressure commonly followed by the loss of the longitudinal midfoot arch, resulting in pronation of the foot. This effected position is a complex tri-planar movement of the subtalar joint which consists of abduction, dorsiflexion, and eversion. ${ }^{6}$

Pronation of the foot is commonly accepted as influencing the kinematic pattern of the lower extremity and leading to structural and functional deficits in both standing and walking. ${ }^{1,7}$ In a closed kinematic chain, pronation of the subtalar joint is characterised by adduction and plantar flexion of the talus and eversion of the calcaneus, leading the talus to slide medially and inferiorly. This medial downward movement of the talus induces an internal rotation of the tibia, valgus of the knee and internal rotation of the hip. . $^{1,8}$

The load-bearing axis of the lower limb can be represented by a line extending from the femoral 
head centre to ankle joint center. ${ }^{9}$ The normal knee joint line alignment is naturally in $2^{\circ}$ to $3^{\circ}$ of varus compared with the mechanical axis..$^{10} \mathrm{In}$ a varus (bow-leg) knee, this line passes medial to the centre of the knee, increasing medial tibiofemoral compartment load and in a valgus (knock-knee) knee, the axis passes lateral to knee centre, increasing force the lateral compartment load. ${ }^{11}$ During gait in the neutrally-aligned knee, the pressure is disproportionately transmitted to the medial tibiofemoral compartment. ${ }^{12}$ The load-bearing axis of the lower limb line is closely associated with the external knee adduction moment (KAM); this indicates the asymmetry or imbalance of loads across the medial and lateral compartments. Increasing of KAM is a valuable surrogate measure of medial compartment joint loading due to its predictive value of osteoarthritis (OA) progression, in which the knee OA more often affects the medial than the lateral compartment. ${ }^{13,14}$

Joint stress across the articular surfaces of the knee can increase compression and shear stress on the tibiofemoral (TF) or patellofemoral (PF) compartments. ${ }^{15}$ That condition can also produce mal-alignment. Furthermore, this can promote cartilage breakdown, osteophyte formation, subchondral bone hypertrophy and lead to progression of knee joint destruction. ${ }^{13}$ Alterations of foot morphology in patients with knee $\mathrm{OA}$ are associated with knee pain, disability and cartilage damage. ${ }^{16}$

\section{METHODS}

\section{Subjects}

The research study sample consisted of 30 subjects who met the inclusion and exclusion criteria. All participants were recruited, evaluated and selected in Sardjito General Hospital of Yogyakarta (Indonesia) according to the following inclusion criteria for all participants: female participants, young age ranging between 18 - 40 years old, body mass index (BMI) of $18-24,9 \mathrm{~kg} / \mathrm{m}^{2}$, and Beighton score $<4$. The exclusion criteria included structural lower limb abnormalities (e.g., leg length discrepancy, arthritis, atrophic muscle disease, neurological deficit, previous surgery history of the lower limb and postural abnormalities). All the recruited participants were signing a written informed consent before participating in the research study. The research study was approved by the institutional ethics committee of the Medical Faculty of Universitas Gadjah Mada Yogyakarta (KE/FK/0026/EC/2018).

\section{Data collection}

An initial physical examination was performed for each participant, including the anthropometric measurement of body weight, body height, shoulder distances, anteriorsuperior iliac spine (ASIS) distances, apparent length (AL) and true length (TL). Calculation of the BMI was using the WHO classification scale (underweight $<18,5 \mathrm{~kg} / \mathrm{m}^{2}$, normal weight 18,5 $-24,9 \mathrm{~kg} / \mathrm{m}^{2}$, overweight $25-29,9 \mathrm{~kg} / \mathrm{m}^{2}$, obese 1 st degree $30-34,9 \mathrm{~kg} / \mathrm{m}^{2}$ and obese 2 nd degree $35-39,9 \mathrm{~kg} / \mathrm{m}^{2}$ ).

To obtain the structural characteristic of both plantar, we used a footprint device using blueprint methods. The plantar area of both feet was ink-coloured, then from the seated position, the participants stood on the blank A4 paper for a while. The examiner also documented the ankle images from behind. The procedure created blue ink imprints on the blank paper which reflected the structure of the plantar area. The same process was performed on all participants while carrying the load of 15 kilograms and 25 kilograms. All of the footprint paper was scanned and evaluated by the J-Image software. The measurements included plantar foot parameters (Figure 1 and 2) and the ankle angle alignment (Figure 3). The interpretation of the ankle angle parameters was as follows: negative if the ankle in varus position and positive if the ankle in a valgus position.

We also performed a Bilateral standing radiographs approach using Digital Diagnost Radiography (DDR) to measure the knee and ankle parameters (Figure 4). The radiographic images were taken three times with the patient stood facing X-ray tube with the knee and hip in normal extension, a distance of both feet equals 
with shoulder distance, and foot abduction were $15^{\circ}$. For the 2 nd and 3rd measurement, we provided different loads; 15 kilograms and
25 kilograms respectively. All of the parameters radiographic results were evaluated by the DICOM viewer image software.

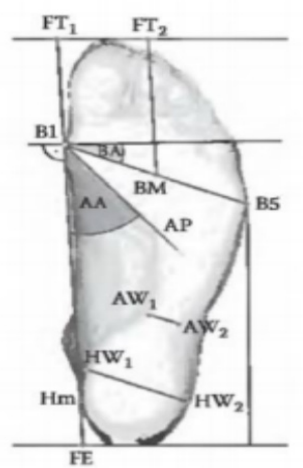

Figure 1. Measured foot parameters.

1. Foot Length $(F L)=$ FT1-FE

2. Toe Length $(T L)=$ FT2-BM

3. Ball of Foot Length $(B F L)=\mathrm{FE}-\mathrm{B} 1$

4. Outside Ball of Foot $(O B F)=$ FE-B5

5. Ball of Foot Width (BFW) = B1-B5

6. Heel Width $(H W)=$ HW1-HW2

7. Plantar Arch Width (PAW) = AW1-AW2

8. Arch Angle $(A A)=$ BFL-AP

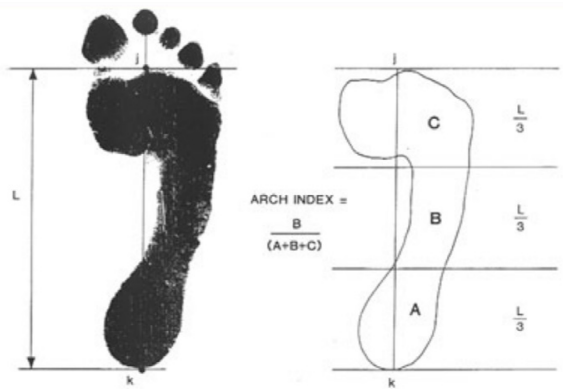

Figure 2. Measured Arch Index (AI).

1. High $\operatorname{arch}(\mathrm{AI} \leq 0,21)$

2. Normal arch $(0,21>\mathrm{AI}>0,26)$

3. Low $\operatorname{arch}(\mathrm{AI} \geq 0,26)$

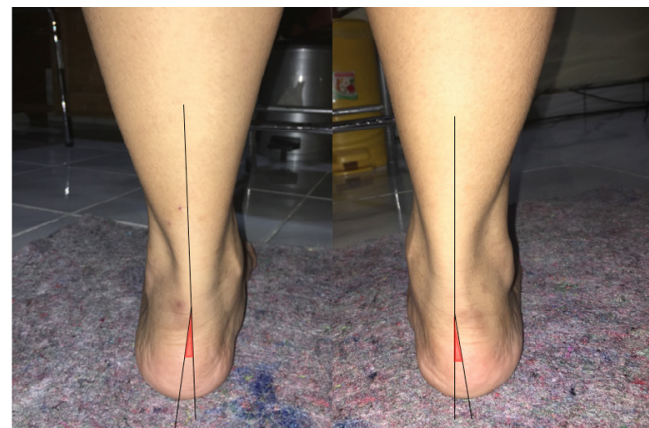

Figure 3. Measured Ankle angle alignment (AAL) 


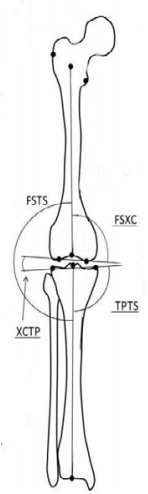

Figure 4. Measured knee and ankle parameters. ${ }^{14}$

\section{Statistical analysis}

This research study applied descriptive statistical methods for the base analysis of the investigated parameters. The statistical analysis and graphic presentation were prepared using statistic software. All the parameters were tested with the Shapiro-Wilk normality test, which resulted in nonparametric value. In terms of study analysis, we used the Wilcoxon test and Spearman correlation to know the significant correlation as well as the strength among the parameters.

\section{RESULTS}

The mean (SD) of age, height, weight, overall BMI of all participants were $20(1,07)$ years, $1,56(0,04) \mathrm{m}, 51,3(5,3) \mathrm{kg}, 20,9(1,3) \mathrm{kg} / \mathrm{m}^{2}$ respectively. Accordingly, the mean (SD) of BMI I with $15 \mathrm{~kg}$ load and BMI II with $25 \mathrm{~kg}$ load were $27(1,19) \mathrm{kg} / \mathrm{m}^{2}$ and $31,1(1,17) \mathrm{kg} / \mathrm{m}^{2}$. The data distribution was shown in Table 1.

In this study (Table 2), increasing BMI to BMI I significantly increased $\mathrm{HW} /$ heel width $(p=0,00)$, with mean differences were 0,22 $\mathrm{cm}$ for the right side and $0,19 \mathrm{~cm}$ for the left side. Furthermore, the increase of BMI to BMI II resulted in mean differences of $0,38 \mathrm{~cm}$ for the right side and $0,31 \mathrm{~cm}$ for the left side. Besides, $\mathrm{PAW} /$ plantar arch width and MFA/mid-foot area were also shown an increase in width and area. The PAW showed $0,33 \mathrm{~cm}$, and $0,77 \mathrm{~cm}$ means differences in the right side compared with BMI to BMI I and BMI II $(p=0,00)$. In addition, the left side also displayed an increased width mean differences of $0,42 \mathrm{~cm}$ and $0,74 \mathrm{~cm}(\mathrm{p}=$ 0,00 ). Accordingly, the MFA parameters showed a similar increased with both parameters. The AA data showed 1,94 $\mathrm{cm}^{2}$ and $3,42 \mathrm{~cm}^{2}$ for the right side $(\mathrm{p}=0,00)$ and $1,49 \mathrm{~cm}^{2}$ and $2,61 \mathrm{~cm}^{2}$ for the left side $(p=0,00)$. The increase of BMI to BMI I also significantly intensified AAL/ankle angle alignment $(p=0,00)$, with mean differences of $2,4^{\circ}$ for the right side and $2,23^{\circ}$. Likewise, the left side showed a significant increase in the parameter for BMI to BMI II, with mean differences of $4,89^{\circ}$ for the right side and $4,48^{\circ}$ for the left side. Also, XCTP/trans-condylar tibial plateau angle and AA/ankle angle showed an

Table 1. The physical parameters of the participants

\begin{tabular}{lcccccc}
\hline & $\begin{array}{c}\text { Age } \\
\text { (Years) }\end{array}$ & $\begin{array}{c}\text { Height } \\
(\mathbf{m})\end{array}$ & $\begin{array}{c}\text { Weight } \\
\mathbf{( K g )}\end{array}$ & $\begin{array}{c}\text { BMI } \\
(\mathbf{K g} / \mathbf{m} 2)\end{array}$ & $\begin{array}{c}\text { BMI I } \\
(\mathbf{K g} / \mathbf{m} 2)\end{array}$ & $\begin{array}{c}\text { BMI II } \\
(\mathbf{K g} / \mathbf{m} 2)\end{array}$ \\
\hline Mean & 20 & 1,56 & 51,3 & 20,9 & 27 & 31,1 \\
SD & 1,07 & 0,04 & 5,3 & 1,3 & 1,19 & 1,17 \\
Max & 23 & 1,64 & 65 & 23,8 & 29,7 & 33,6 \\
Min & 19 & 1,5 & 44 & 19,6 & 25,8 & 30 \\
Test of normality* & & & & 0,00 & 0,00 & 0,00 \\
\hline *Shapiro wilk & & & & & &
\end{tabular}


Table 2. The mean differences of the parameters

\begin{tabular}{llllllllllll}
\hline & & \multicolumn{3}{c}{ I } & \multicolumn{3}{c}{ II } & \multicolumn{3}{c}{ III } \\
\cline { 2 - 11 } & & Mean & SD & Mean & SD & Mean dif. & Sig. & Mean & SD & Mean dif. & Sig \\
\hline HW & Right & 4,05 & 0,38 & 4,27 & 0,40 & 0,22 & 0,00 & 4,42 & 0,34 & 0,38 & 0,00 \\
& Left & 4,11 & 0,39 & 4,30 & 0,36 & 0,19 & 0,00 & 4,41 & 0,36 & 0,31 & 0,00 \\
\multirow{2}{*}{ PAW } & Right & 2,52 & 0,43 & 2,85 & 0,35 & 0,33 & 0,00 & 3,29 & 0,42 & 0,77 & 0,00 \\
& Left & 2,53 & 0,36 & 2,95 & 0,32 & 0,42 & 0,00 & 3,27 & 0,30 & 0,74 & 0,00 \\
\multirow{2}{*}{ MFA } & Right & 18,43 & 2,29 & 20,36 & 2,31 & 1,94 & 0,00 & 21,85 & 2,98 & 3,42 & 0,00 \\
& Left & 18,67 & 2,66 & 20,17 & 2,98 & 1,49 & 0,00 & 21,29 & 3,14 & 2,61 & 0,00 \\
AAL & Right & 2,20 & 2,05 & 4,60 & 1,69 & 2,40 & 0,00 & 7,10 & 2,18 & 4,89 & 0,00 \\
& Left & 2,17 & 2,37 & 4,40 & 1,82 & 2,23 & 0,00 & 6,66 & 1,83 & 4,48 & 0,00 \\
XCTP & Right & 0,70 & 1,92 & 0,96 & 1,91 & 0,26 & 0,00 & 1,28 & 1,97 & 0,58 & 0,00 \\
& Left & 0,81 & 1,89 & 1,01 & 1,89 & 0,20 & 0,00 & 1,32 & 2,00 & 0,51 & 0,00 \\
AA & Right & $-1,39$ & 1,53 & $-0,79$ & 1,66 & 0,60 & 0,00 & $-0,34$ & 1,73 & 1,05 & 0,00 \\
& Left & $-1,53$ & 1,42 & $-0,97$ & 1,55 & 0,57 & 0,00 & $-0,60$ & 1,66 & 0,94 & 0,00 \\
\hline
\end{tabular}

HW = Heel width, PAW = Plantar arch width, MFA = Midfoot area, AAL = Ankle angle alignment, $\mathrm{XCTP}=$ transcondylar tibial plateau angle, $\mathrm{AA}=$ Ankle angle

increased angle degree. The XCTP displayed $0,26^{\circ}$ and $0,58^{\circ}$ of mean differences on the right side by comparing the increase of BMI to BMI I and BMI II $(p=0,00)$. Moreover, the left side also showed increased angle $0,2^{\circ}$ and $0,51^{\circ}$ of mean differences $(p=0,00)$. Regarding the AA parameters, this demonstrated a similar increase of $0,6^{\circ}$ and $1,05^{\circ}$ for the right side $(p=0,00)$ and $0,57^{\circ}$ and $0,94^{\circ}$ for the left side $(\mathrm{p}=0,00)$.

The Spearman correlation test (Table 3) showed a significant correlation between BMI and HW/heel width $(\mathrm{p}=0,00)$ but low positive correlation $(r=0,36)$ for the right side and $(r=0,35)$ for left side. Furthermore, the correlation of BMI and PAW showed an equally significant correlation $(\mathrm{p}=0,00)$, with moderate positive correlation $(r=0,59)$ for both sides. In addition, the correlation of BMI and MFA ( $\mathrm{p}=$ 0,00 ) showed a moderate positive correlation $(r=0,45)$ for the right side and low positive correlation $(r=0,35)$ for left side. Likewise, the correlation between $\mathrm{BMI}$ and $\mathrm{AI} / \mathrm{arch}$ index also showed a significant correlation $(p=0,00)$ with strong positive correlation $(r=0,67)$ for the right side and moderate positive correlation ( $\mathrm{r}$ $=0,59$ ) for left side. This study also revealed the strong positive correlation of BMI and AAL ( $p$ $=0,00$ ) on both sides, with $r=0,67$ and $r=0,64$ for the right and left side. Besides, the XCTP and AA parameters also displayed a significant correlation $(p<0,05)$ for both sides, however the correlation was low positive $(r=0,20-0,40)$. The scatter plot showed the data distribution to demonstrate the course of correlation (Table 4).

Table 3. Correlation test between BMI, plantar parameters and ankle-knee parameters

\begin{tabular}{|c|c|c|c|c|c|c|c|c|c|c|c|c|c|c|}
\hline & \multicolumn{2}{|c|}{ HW } & \multicolumn{2}{|c|}{ PAW } & \multicolumn{2}{|c|}{ MFA } & \multicolumn{2}{|c|}{ AI } & \multicolumn{2}{|c|}{ AAL } & \multicolumn{2}{|c|}{ XCTP } & \multicolumn{2}{|c|}{ AA } \\
\hline & $\mathbf{R}$ & $\mathbf{L}$ & $\mathbf{R}$ & $\mathbf{L}$ & $\mathbf{R}$ & $\mathbf{L}$ & $\mathbf{R}$ & $\mathbf{L}$ & $\mathbf{R}$ & $\mathbf{L}$ & $\mathbf{R}$ & $\mathbf{L}$ & $\mathbf{R}$ & $\mathbf{L}$ \\
\hline \multicolumn{15}{|l|}{ BMI } \\
\hline $\begin{array}{l}\text { Correlation } \\
\text { coefficient* }\end{array}$ & 0,36 & 0,35 & 0,59 & 0,59 & 0,45 & 0,35 & 0,67 & 0,59 & 0,67 & 0,64 & 0,27 & 0,23 & 0,31 & 0,31 \\
\hline Sig. (2 tailed) & 0,00 & 0,00 & 0,00 & 0,00 & 0,00 & 0,00 & 0,00 & 0,00 & 0,00 & 0,00 & 0,01 & 0,03 & 0,00 & 0,00 \\
\hline
\end{tabular}

HW = Heel width, PAW = Plantar arch width, MFA = Midfoot area, AI = Arch index, AAL = Ankle angle alignment, $\mathrm{XCTP}=$ transcondylar tibial plateau angle, AA = Ankle angle, ${ }^{*}$ Spearman correlation 
Table 4. Scatter plot between BMI, plantar parameters and ankle-knee parameters
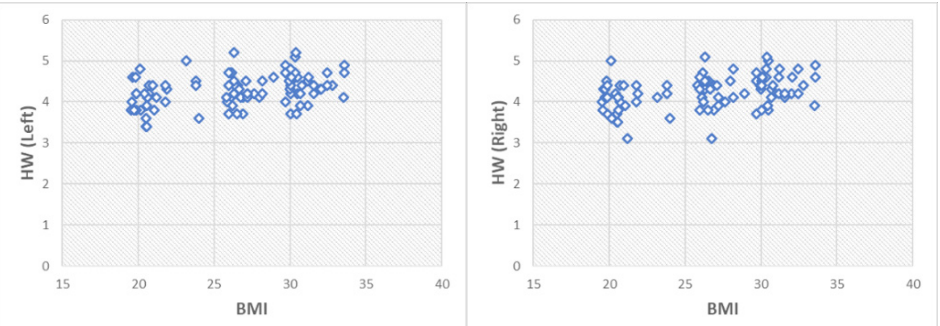

Scatter plot between BMI and HW (right side and left side)
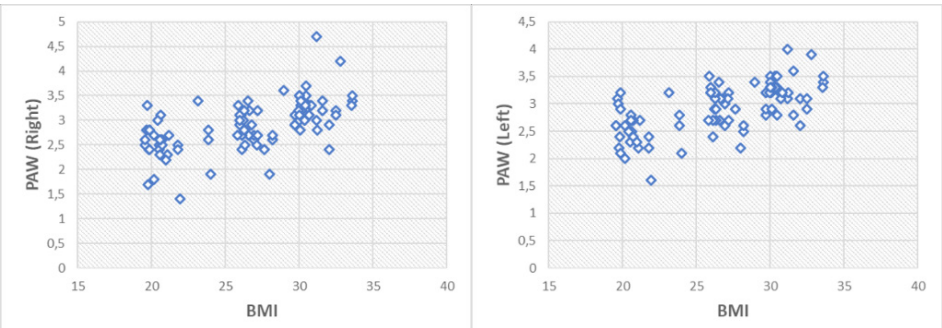

Scatter plot between BMI and PAW (right side and left side)

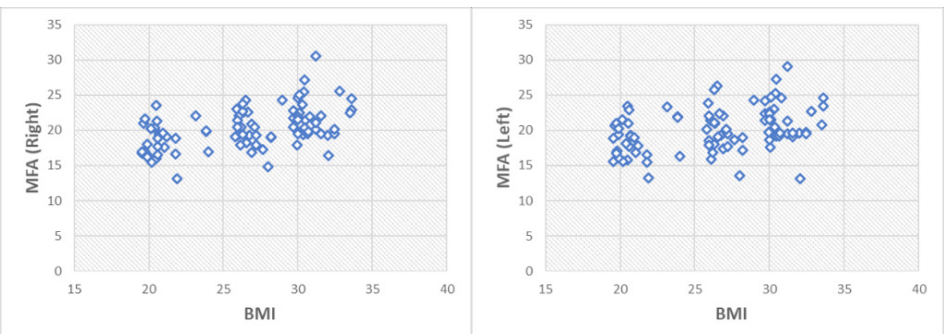

Scatter plot between BMI and MFA (right side and left side)

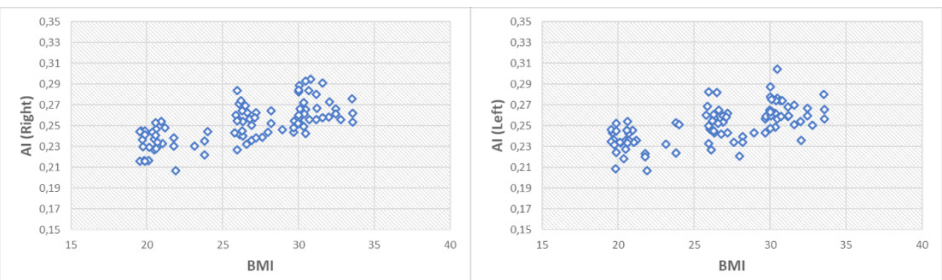

Scatter plot between BMI and AI (right side and left side)
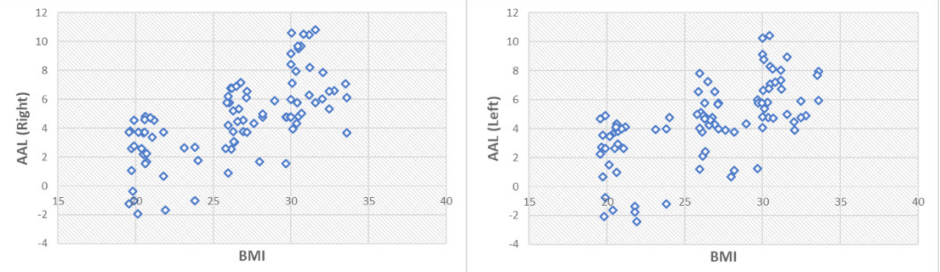

Scatter plot between BMI and AAL (right side and left side)
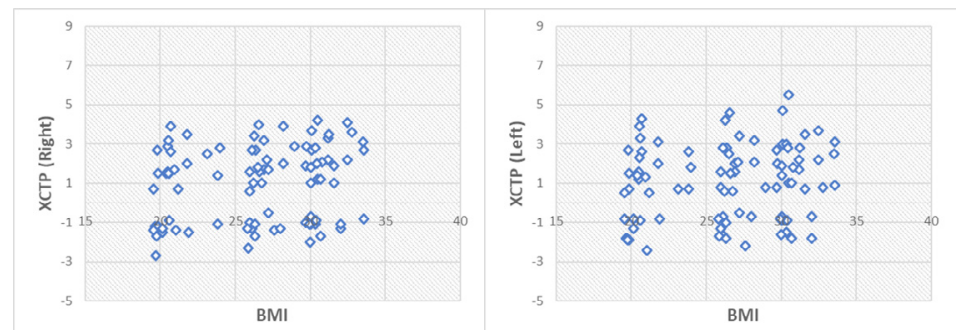

Scatter plot between BMI and XCTP (right side and left side) 


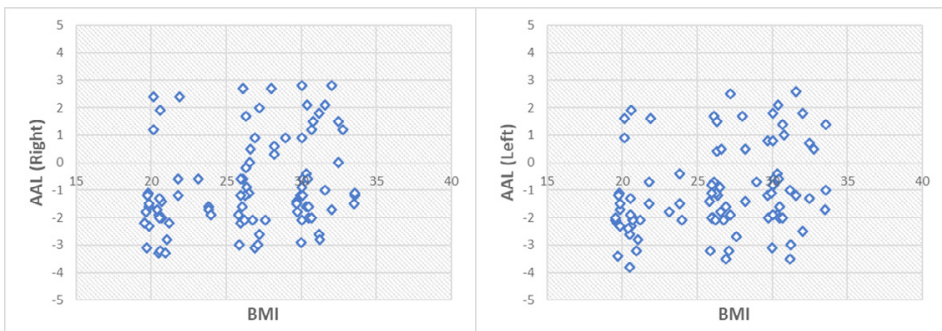

Scatter plot between BMI and AAL (right side and left side)

\section{DISCUSSION}

The knowledge of biomechanics and the interaction of the multisegmental of the body structure is crucial. The problem related to the body segment could influence the adjacent structure and tend to affect the musculoskeletal function. This study was performed to examine and to find the effect of increasing body weight on plantar pressures and ankle-knee angle parameters. We found a significant association between change in body weight with both plantar pressures and ankle-knee angle. This finding is similar to previous research which showed a positive relationship between increased body mass with peak and means plantar pressure. ${ }^{4}$ Data retrieval taken in this research study was in agreement with the Murly (2009), in which the classification of the foot posture could be visible from visual observations, measurement of navicular height or mid-foot height, footprint measures and angular measures derived from radiographs. ${ }^{17}$ The additional weight added to the participants was intended to increase their BMI into the weight classes of "overweight" and "obese".

According to Pirozzi (2014), such procedure is performed to distribute the anterior and posterior weight evenly, which have adjustable shoulder, chest, and waist strap for uniform pressure distribution. ${ }^{18}$ In addition, previous studies investigating the effect of increasing body weight on plantar pressure were also traditionally done using weighed backpacks. ${ }^{2}$ To calculate "foot arch", there are known various methods, among them, are the arch (Clarke) angle, Chippaux-Smirak index, Staheli index, arch length index, arch index, footprint index and truncated arch index. The footprint method is relatively fast, simple, non-invasive and costeffective of an indirect method. ${ }^{3}$

The increase of body weight is strongly associated with the loss of the medial longitudinal arch of the foot posture, a condition known as flat foot, which initiated pronated dynamic foot function. In contrast, the increase of the mid-foot area (MFA) correlates with the higher arch index score (low arch/AI $\geq 0,26$ ) as well as the AAL/ ankle angle alignment and AA/ankle angle which tend to valgus value. ${ }^{19}$ Our results showed that increasing body weight was positively correlated with increasing HW, PAW and MFA values. This was in agreement with the study by Pirozzi (2014), which suggested that an increase in body weight corresponds to pressure noted on the heel, mid-foot, forefoot, and the first metatarsal. ${ }^{18}$

The previous study by Tomankova (2015) revealed that subjects with a lower arch appeared to have a greater BMI. ${ }^{5}$ Accordingly, other study showed that low arch of midfoot cause malalignment of the proximal lower extremity, frequently leading to structural and functional deficits. ${ }^{1}$ The presence of excessive low arch leading to calcaneal eversion generates valgus of the knee joint, internal rotation of the tibia and femur. ${ }^{7}$

Our study showed that the increase in body weight was positively correlated with an increase in XCTP values, which displayed an increase in strength in the lateral compartment and reduced the medial load. This indicates a decline in the value of knee adduction moment (KAM), where the load-bearing axis laterally to the knee centre. Usually, during a stance phase and also normal gait in healthy knees, more load passes through 
the medial tibiofemoral compartment, then goes through laterally. ${ }^{12}$ This is also explained that the load-bearing axis medially to knee centre, creating a moment arm. ${ }^{9}$

The correlation between BMI that induces hyper-pronation, valgus ankle and the valgus knee were described appropriately by Ghasemi (2016), Letafatkar (2013) and Reischl (1999).,7,8 Their study illustrated that hyper-pronation produced more proximal biomechanical dysfunction and resulted in larger tibial rotations. The rotation of the tibia is in response to the medial rotation/adduction of the talus as it falls into the space created by the inferior and lateral motions of the calcaneus. Consequently, the increase in pronation results in internal rotation of the tibia and excessive femur, leading to an increase in rotational pressure on the knee. Excessive internal femoral rotation causes the lateral trochlea femur to be adjacent to the lateral patella and also increased contact between the lateral joint articulation surfaces. ${ }^{15}$ This condition also occurs in women; a higher Q-angle increases the lateral pull of the quadriceps femoris muscle on the patella and internal tibial rotation potentiates patellofemoral disorder. If this condition occurs for an extended period, it will result in the decreased musculoskeletal function and lower extremity joint disorders (e.g. patellofemoral pain, anterior knee pain and iliotibial band syndrome). ${ }^{6}$

\section{CONCLUSION}

The results revealed that increasing body weight was found to have statistically significant correlations $(p<0,005)$ with increasing of the heel width (HW), plantar arch width (PAW), mid-foot area (MFA), arch index (AI), ankle angle alignment (AAL), trans-condylar tibial plateau angle radiograph (XCTP) and ankle angle radiograph (AA). Increasing body weight was associated with increased plantar pressure and ankle-knee radiographs angle parameters. In other word, each one of them was a compensatory phenomenon which can lead to structural changes and decrease musculoskeletal function.

\section{ACKNOWLEDGMENT}

None declare

\section{Conflict of interest}

None declare.

\section{REFERENCES}

1. Ghasemi MS, Koohpayehzadeh J, Kadkhodaei H, Ehsani AA. The effect of foot hyperpronation on spine alignment in standing position. Medical Journal of The Islamic Republic of Iran. 2016;30(1).

2. Walsh TP, Butterworth PA, Urquhart DM, et al. Increase in body weight over a two-year period is associated with an increase in midfoot pressure and foot pain. Journal of Foot and Ankle Research. 2017;10(1):4-11.

3. Ozer CM, Barut AC. Evaluation of the sole morphology of professional football players. International Journal of Sports Medicine. 2012;13(1):8-17.

4. Arnold JB, Causby R, Jones S. The impact of increasing body mass on peak and mean plantar pressure in asymptomatic adult subjects during walking. Diabet Foot Ankle. 2010;1(March).

5. Tomankova K, Pridalova M, Gaba A. The impact of obesity on foot morphology in women aged 48 years or older. Acta Gymnica. 2015;45(2):69-75.

6. Hetsroni I, Finestone A, Milgrom C, et al. A prospective biomechanical study of the association between foot pronation and the incidence of anterior knee pain among military recruits. The Journal of bone and joint surgery. British volume. 2006;88-B(7):9058.

7. Reischl SF, Powers CM, Rao S, Perry J. Relationship between foot pronation and rotation of the tibia and femur during walking. Foot \& Ankle International: SAGE Journals. 1999;20(8):513-20.

8. Letafatkar A. Flat Foot Deformity, Q Angle and Knee Pain are Interrelated in Wrestlers. Journal of Novel Physiotherapies. 2013;03(02):2-7.

9. Sharma L, Song J, Dunlop D, et al. Varus and Valgus Alignment and Incident and Pro- 
gressive Knee Osteoarthritis. Annals of the rheumatic diseases. 2010;69(11):1940-5.

10. Cherian JJ, Kapadia BH, Banerjee S, Jauregui JJ, Issa K, Mont MA. Mechanical, anatomical, and kinematic axis in TKA: Concepts and practical applications. Current Reviews in Musculoskeletal Medicine. 2014;7(2):8995.

11. Sharma L, Lou C, Cahue S, Dunlop DD. The mechanism of the effect of obesity in knee osteoarthritis: The mediating role of malalignment. Arthritis \& Rheumatism. 2000;43(3):568-75.

12. Sharma $L$. The role of varus and valgus alignment in knee osteoarthritis. Arthritis \& Rheumatism. 2007;56(4):1044-47.

13. Messier SP, Pater M, Beavers DP, et al. Influences of Alignment and Obesity on Knee Joint Leading in Osteoarthritic Gait. Osteoarthritis and Cartilage. 2014;23(6):839-52.

14. Matsumoto T, Hashimura $M$, Takayama $\mathrm{K}$, et al. A radiographic analysis of alignment of the lower extremities - initiation and progression of varus-type knee osteoarthritis. Osteoarthritis and Cartilage. 2015;23(2):217-23.

15. Gross KD, Felson DT, Niu J, et al. Flat Feet Are Associated With Knee Pain and Cartilage Damage in Older Adults. Arthritis care \& research American College of Rheumatology. 2011;9(2):225-40.

16. Ohi H, Iijima H, Aoyama T, Kaneda E, Ohi $\mathrm{K}$, Abe K. Association of frontal plane knee alignment with foot posture in patients with medial knee osteoarthritis. BMC Musculoskeletal Disorders. 2017;18(1):1-10.

17. Murley GS, Menz HB, Landorf KB. A protocol for classifying normal- and flat-arched foot posture for research studies using clinical and radiographic measurements. Journal of Foot and Ankle Research. 2009;2(1):113.

18. Pirozzi K, McGuire J, Meyr AJ. Effect of variable body mass on plantar foot pressure and off-loading device efficacy. Journal of Foot and Ankle Research. 2014;53(5):58897.

19. Pezzan PAO, Sacco ICN, João SMA. Foot posture and classification of the plan- tar arch among adolescent wearers and non-wearers of high-heeled shoes. The Brazilian Journal of Physical Therapy. 2009;13(5):398-404. 